\title{
PROTOTIPE SISTEM INFORMASI PENGELOLAAN DATA STATISTIK TERPADU KOTA BONTANG
}

\author{
Lapu Tombilayuk ${ }^{1)}$, Zaini ${ }^{2)}$ \\ ${ }^{1)}$ Teknik Informatika, Sekolah Tinggi Teknologi Bontang \\ ${ }^{2)}$ Teknik Elektro, Sekolah Tinggi Teknologi Bontang \\ Email: tombilayuk01@gmail.com ${ }^{1)}$,Zaini.math@gmail.com ${ }^{2)}$
}

\begin{abstract}
Abstrak - Kebutuhan sebuah sistem Informasi yang dapat menginput data sektoral di masing-masing organisasi perangkat daerah (OPD) yang dapat diintegrasikan dengan sistem yang ada, sangat diperlukan oleh instansi pemerintah secara khusus pemerintah Kota Bontang. Permasalahan yang ada pada saat ini adalah sebaran data sektoral yang terdapat pada masing-masing OPD Kota Bontang, belum bisa diakses dan diolah secara cepat oleh Dinas Komunikasi, Informatika dan Statistik Kota Bontang karena belum ada sistem yang dapat mengintegrasikan sebaran data tersebut. Berdasarkan permasalah tersebut maka diperlukan prototipe sistem informasi pengolahan data statistik terpadu Kota Bontang, yang diharapkan dapat memberikan gambaran perancangan sistem yang dapat mengaskses sebaran data statistik terpadu secara cepat dan terintegrasi. Dalam perancangan prototipe ini, peneliti melakukan beberapa tahap yaitu pertama analisis sistem yang sedang berjalan melalui metode pengamatan langsung, wawancara dengan pengelolah data statistik, sehingga diperolah gambaran proses bisnis sistem yang sedang berjalan. Tahap kedua adalah metode penggambaran atau pemodelan sistem yang akan dibangun dengan menggunakan pemodelan logic (logical model) dengan membuat diagram konteks, diagram alir data (DFD) level 0 -seterusnya, perancangan basis data dan perancangan antar muka (interface) sistem. Dari penelitian ini menghasilkan rancangan prototipe sistem informasi yang digunakan oleh Tim perancangan sistem untuk membangun sistem informasi Pengelolaan Data Statistik Terpadu (SIMPATIKU) Kota Bontang.
\end{abstract}

Kata Kunci-Statistik, Prototype, Sektoral

\section{PENDAhUluAN}

Berdasarkan peraturan Kepala Badan Pusat Statistik nomor 9 tahun 2019 pada Bab II pasal 2 menyatakan bahwa statistik sektoral diselenggarakan oleh Pemerintah Daerah sesuai dengan tugas pokok dan fungsinya, secara mandiri atau melalui kerjasama daerah. Dalam menyelenggarakan kegiatan statistik sektoral, Pemerintah Daerah memperoleh data melalui survei, kompilasi produk administrasi, dan cara lain sesuai dengan perkembangan ilmu pengetahuan dan teknologi.

Dinas Komunikasi, Informatika dan Statistik merupakan instansi yang bergerak dibidang komunikasi, informatika dan statistik yang meliputi bidang telekomunikasi, sarana komunikasi serta pengolahan data statistik yang mempunyai tugas yaitu mengkoordinasikan dan sebagai pembinaan perangkat daerah dan melaksanakan tugas lain dari Walikota sesuai tugas dan masing-masing fungsinya. Selain itu dinas dalam melakukan pengolahan dan elektronik telah menggunakan teknologi telekomunikasi berupa jaringan komputer dalam mengkomunikasikan antar perangkat daerah satu dengan lainnya yang terdapat di Kota Bontang. Namun berkaitan dengan tugas dan fungsi dalam melaksanakan urusan statistik Kota Bontang, berperan dalam penyediaan data dan informasi untuk kebutuhan perencanaan, pengendalian, evaluasi dan pelaporan.
Adapun permasalahan yang terdapat dalam fungsi statistik yaitu terkendala dalam melakukan pengumpulan dan validasi data-data yang dihasilkan dari organisasi perangkat daerah, adapun penyebab terkendalanya karena ketersedian data masih secara manual yang disediakan oleh perangkat daerah. Dan organisasi perangkat daerah sebagian masih lemah dalam melakukan penyediaan data maupun dalam melakukan pemutahiran data, yang menyembabkan data-data yang tersedia menjadi tidak valid.

\subsection{Tujuan Penelitian}

Tujuan penelitian yang akan dicapai pada penelitian ini adalah menghasilkan prototye sistem informasi yang dapat mengolah data statitistik sektoral yang berasal dari Organisasi Perangkat Daerah Pemerintah Kota, yang dapat dijadikan acuan untuk membangun sistem informasi pengolahan data statistik terpadu (SIMPATIKU) Kota Bontang.

\section{METODE}

\subsection{Metode Penelitian}

2.1.1 Lokasi Penelitian

Lokasi penelitian adalah adalah Dinas

Komunikasi, Informatika dan Statistik (DISKOMINFOTIK) Kota Bontang. Subjek penelitian adalah data statistik sektoral yang berasal dari Organisasi Perangkat Daerah (OPD) Kota Bontang. 


\subsubsection{Teknik Pengumpulan Data}

1) Observasi

Adalah metode atau cara-cara untuk megamati keadaan yang wajar dan yang sebenarnya.

2) Studi pustaka

Adalah motode pengumpulan data yang bersumber dari buku referensi, jurnal, paper, website dan bacaan-bacaan yang ada kaitannya dengan judul penelitian yang dapat menunjang pemecahan permasalahan yang didapatkan dalam penelitian.

\section{3) Wawancara}

Merupakan teknik pengumpulan data yang dilakukan melalui tatap muka dan tanya jawab langsung antara pengumpul data terhadap narasumber / sumber data.

\subsubsection{Metode Pembangunan Sistem}

Pada penelitian ini metode perancangan aplikasi yang digunakan adalah waterfall. Metode Waterfall menyarankan pengembangan perangkat lunak secara sistematik dan berurutan yang dimulai dari tingkatan sistem tertinggi dan berlanjut ketahap analisis, desain, pengkodean, pengujian dan pemeliharaan. Kelebihan dari metode ini adalah terstruktur, dinamis, dan sequintal.

Tahap dimana menentukan kebutuhan-kebutuhan bagi seluruh elemen-elemen sistem, kemudian mengalokasikan beberapa subset dari kebutuhankebutuhan tersebut bagi perangkat. Gambaran sistem merupakan hal yang penting pada saat perangkat lunak harus berinteraksi dengan elemen sistem lain seperti perangkat keras, manusia dan database. Requitment System mencakup kumpulan kebutuhan pada setiap tingkat teratas perancangan dan analisis [1].

\section{1) Analysis}

Tahap dimana kita menterjemahkan kebutuhan pengguna ke dalam spesifikasi kebutuhan sistem atau SRS (System Requirement Spesification). Spesifikasi kebutuhan sistem ini bersifat menangkap semua $\quad$ yang dibutuhkan sistem dan dapat terus diperbaharui secara iterative selama berjalannya proses pengembangan sistem.

\section{2) Design}

Tahap dimana dimulai dengan pernyataan masalah dan diakhiri dengan rincian perancangan yang dapat ditransformasikan ke sistem operasional. Transformasi ini mencakup seluruh aktivitas pengembangan perancangan [2].

\section{3) Coding}

Melakukan penghalusan rincian perancangan ke penyebaran sistem yang sesuai dengan kebutuhan pengguna. Transformasi ini juga mencakup perancangan peralatan yang digunakan, prosedur- prosedur pengoperasian, deskripsi orang-orang yang akan menggunakan sistem dan sebagainya.

4) Implementasi

Implementasi yang akan digunakan meliputi proses pengaplikasian aplikasi yang sesuai dengan perancangan awal, dan membuat prototype untuk mengetahui kekurangan atau masalah yang dihadapi. 5) Evaluasi

Evaluasi yang digunakan dalam pembuatan aplikasi tersebut yaitu evaluasi sistem. Evaluasi sistem dengan melakukan percobaan-percobaan kepada aplikasi tersebut dan mencari kekurangankekurangan yang ada serta memperbaikinya [1].

\subsubsection{Sistem Informasi}

Sistem Informasi adalah gabungan dari perangkat lunak (software), perangkat keras (hardware), infrastruktur, dan sumber daya manusia (SDM) yang terlatih. Keempat bagian utama ini saling berkaitan untuk menciptakan atau menghasilkan sebuah sistem yang dapat mengolah data menjadi informasi yang bermanfaat. Di dalamnya juga termasuk proses, perencana, kontrol, koordinasi, dan pengambilan keputusan. Sehingga, sebagai sebuah sistem yang mengolah data menjadi informasi yang akan disajikan dan digunakan oleh pengguna, maka sistem informasi merupakan sebuah sistem yang kompleks [3].

\subsubsection{Data}

Adalah deskripsi tentang benda, kejadian, aktifitas dan transaksi yang tidak mempunyai makna atau tidak berpengaruh secara langsung kepada pemakai. Sedangkan informasi adalah data yang diolah menjadi sebuah bentuk yang berarti bagi penerimanya dan bermanfaat dalam mengambil keputusan saat ini atau mendatang [4].

Jenis-jenis data dapat dibagi berdasarkan sifatnya, sumbernya, cara memperolehnya dan waktu pengumpulannya. Menurut sifatnya, jenis-jenis data yaitu:

1. Data Kualitatif

Adalah data yang tidak berbentuk angka, misalnya: kuesioner pertanyaan tentang suasana kerja, kualitas pelayanan sebuah rumah sakit atau gaya kepemimpinan dan lain-lain.

\section{Data Kuantitatif}

Adalah data yang berbentuk angka, misalnya: harga saham, besarnya pendapatan dan lain-lain. Jenis-jenis data menurut sumbernya, antara lain:

a. Data Internal

Adalah data dari dalam suatu organisasi yang menggambarkan keadaan organisasi tersebut. Contohnya: suatu perusahaan, jumlah karyawannya, jumlah modalnya atau jumlah produksinya dan lainlain. 


\section{b. Data Eksternal}

Adalah data dari luar suatu organisasi yang dapat menggambarkan faktor-faktor yang mungkin mempengaruhi hasil kerja suatu organisasi. Misalnya daya beli masyarakat mempengaruhi hasil penjualan suatu perusahaan.

\subsubsection{Pembangunan Atau Perancangan}

Perancangan adalah kegiatan dengan membuat sebuah pola sistem baru yang bertujuan untuk mengembangkan sistem sebelumnya dan dapat digunakan untuk memecahkan masalah.

Pada pembangunan dan pengembangan sistem informasi digunakan metode Air terjun (WaterFall) sering juga disebut model sekuensial linier (sequential linier) atau alur hidup klasik (classic life cycle). Model air terjun menyediakan pendekatan alur hidup perangkat lunak secara sekuential atau terurut dimulai dari analisis, desain, pengkodean, pengujian, dan tahap pendukung (support) [5].

1) Analisis Kebutuhan Perangkat Lunak

Proses pengumpulan kebutuhan dilakukan secara intensif untuk menspesifikasikan kebutuhan perangkat lunak agar dapat dipahami perangkat lunak seperti apa yang dibutuhkan oleh user.

Spesifikasi kebutuhan perangkat lunak pada tahap ini perlu untuk didokumentasikan [6].

2) Desain

Desain perangkat lunak adalah proses multi langkah yang fokus pada desain pembuatan program perangkat lunak termasuk struktur data, arsitektur perangkat lunak, representasi antarmuka, dan prosedur pengkodean. Tahap ini mentrannslasi kebutuhan perangkat lunak dari tahap analisis kebutuhan ke representasi desain agar dapat diimplementasikan menjadi program pada tahap selanjutnya. Desain perangkat lunak yang dihasilkan pada tahap ini juga perlu didokumentasikan [7].

3) Pembuatan Kode Program

Desain harus ditranslasikan kedalam program perangkat lunak. Hasil dari tahap ini adalah program komputer sesuai dengan desain yang telah dibuat pada tahap desain.

4) Pengujian

Pengujian fokus pada perangkat lunak secara dari segi lojik dan fungsional dan memastikan bahwa semua bagian sudah diuji. Hal ini dilakukan untuk meminimalisir kesalahan (error) dan memastika keluaran yang dihasilkan sesuai dengan yang diinginkan.

5) Pendukung atau Pemeliharaan (maintenance)

Tidak menutup kemungkinan sebuah perangkat lunak mengalami perubahan ketika sudah dikirimkan ke user. Perubahan bisa terjadi karena adanya kesalahan yang muncul dan tidak terdeteksi saat pengujian atau perangkat lunak harus beradaptasi dengan lingkungan baru.

Tahap pendukung atau pemeliharaan dapat mengulangi proses pengembangan mulai dari analisis spesifikasi untuk perubahan perangkat lunak yang sudah ada, tapi tidak untuk membuat perangkat lunak baru [8].

\section{6) Prototype}

Sering, seorang pengguna mendefinisikan sekelompok tujuan umum untuk sebuah sistem tetapi tidak mengidenfikasi detail input, proses, atau output yang diperlukan. Pada kasus lain, pengembang mungkin tidak mengetahui secara pasti dari efisiensi sebuah algoritma, kemampuan adaptasi dari sebuah sistem operasi, atau form interaksi antara manusia dan mesin yang seharusnya digunakan. Oleh karena itu pada situasi seperti ini langkah pembuatan prototipe merupakan salah satu langkah pemecahan terbaik [9].

Prototipe merupakan simulasi atau animasi dari bakal sistem. Prototipe merupakan suatu metode dalam pengembangan sistem yang menggunakan pendekatan untuk membuat suatu program dengan cepat dan bertahap sehingga segera dapat dievaluasi oleh pemakai. Prototipe dapat dianggap sebagai sistem awal. Tetapi mungkin ini pandangan yang ideal. Memang benar jika pengguna dan pengembang senang menggunakan langkah pembuatan prototipe. Pengguna dapat merasakan sistem secara langsung dan pengembang dapat membangun sistem secara cepat [10].

\section{HASIL DAN PEMBAHASAN}

\subsection{Hasil Penelitian}

\section{1) Diagram Konteks Sistem Yang Dirancang}

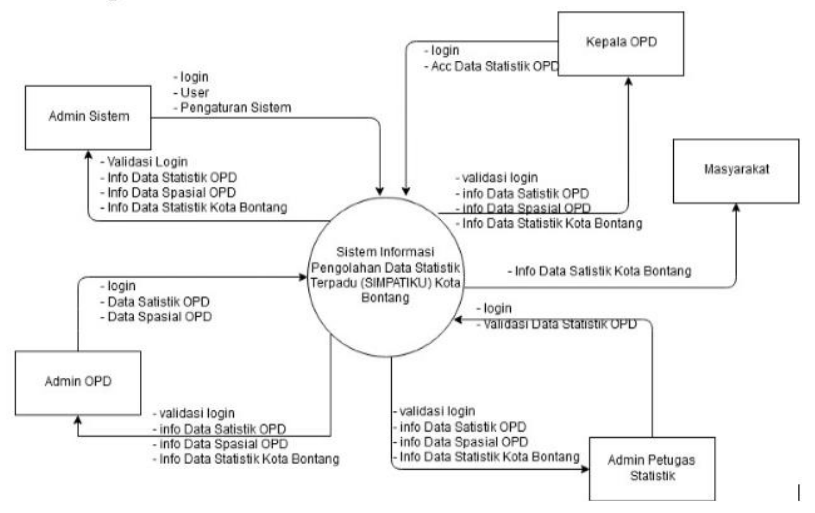

Gambar 1 Diagram Konteks Sistem Yang Dirancang

Gambar 1 menggambarkan 5 (lima) entitas pengguna, yang terdiri dari Admin sistem (super admin), admin oraganisasi perangkat daerah (OPD), admin petugas statistik, kepala OPD, dan masyarakat 
JUST TI: (Jurnal Sains Terapan Teknologi Informasi) 12, 2 (Juli, 2020): 59-65

ISSN: 2579-4510(online) ISSN: 2085-6458(print)

yang akan melihat data statistik sektoral Kota Bontang. Admin sistem melakukan pengaturan sistem dengan mendaftarkan semua user yang akan berinteraksi dengan sistem.

2) Diagram Arus Data (Data Flow Diagram) Sistem Yang Dirancang

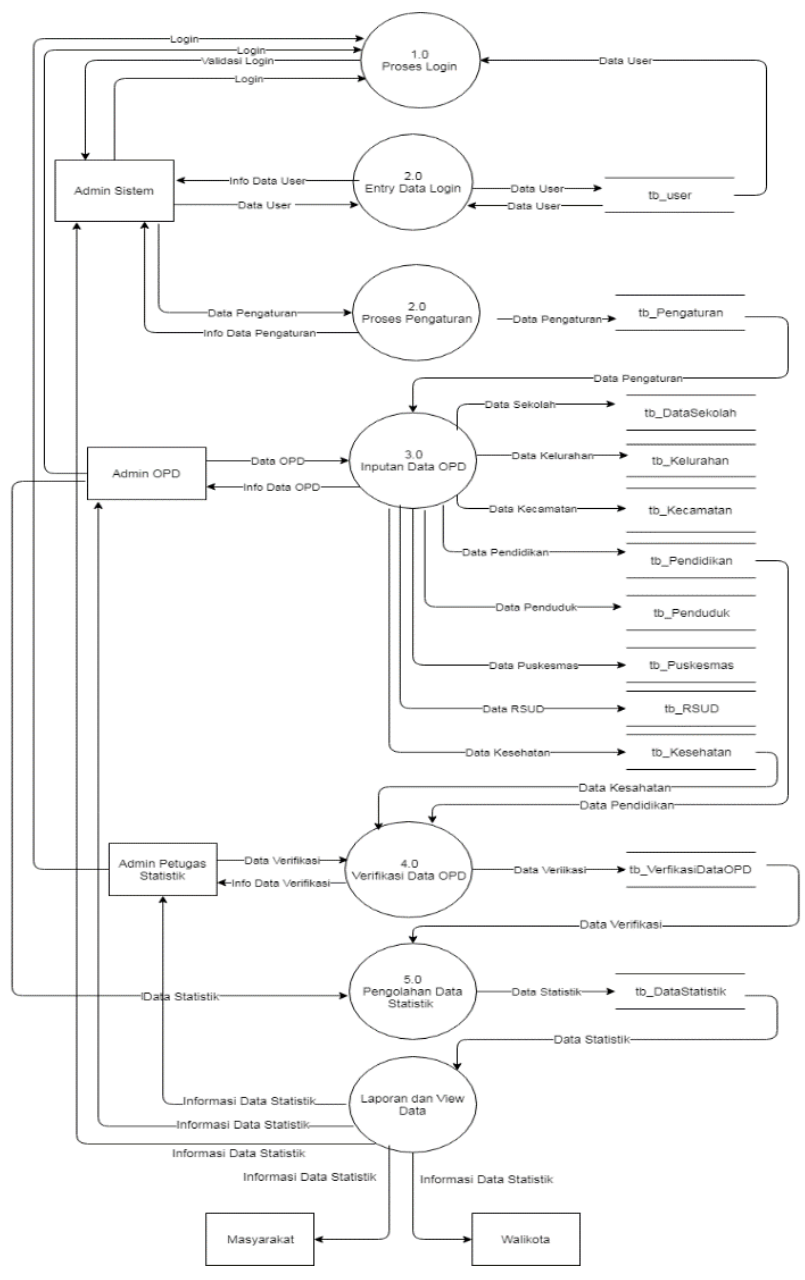

Gambar 2 Diagram Arus Data Sistem Yang Dirancang

Pada gambar 2 mengambarkan diagram arus data yaitu penjabaran dari diagram konteks, dimana dapat memperlihatkan data-data yang mengalir dalam sistem, melalui proses apa dan siapa (user) yang melakukan proses tersebut. Dari diagram ini menampilkan lima entitas pengguna (user) yaitu admin sistem, admin organisasi perangkat daerah (OPD), admin petugas Statistik, masyarakat dan Walikota.

3) Tabel User
Tabel 1 Tabel User

\begin{tabular}{c|l|c|c|l}
\hline No & \multicolumn{1}{c}{$\begin{array}{c}\text { Nama } \\
\text { Field }\end{array}$} & \multicolumn{1}{c}{$\begin{array}{c}\text { Tipe } \\
\text { Data }\end{array}$} & Lebar & Keterangan \\
\hline 1 & id_user & Varchar & 5 & Id user \\
\hline 2 & nama_user & Varchar & 15 & Nama user \\
\hline 3 & Password & Varchar & 15 & Sandi user \\
\hline 4 & Email & Varchar & 30 & Email user \\
\hline 5 & No_tlp & Int & 13 & $\begin{array}{l}\text { Nomor } \\
\text { telepon user }\end{array}$ \\
\hline
\end{tabular}

Dari tabel 4 menampilkan tabel pengguna (user), yang terdiri dari 5 field atau variabel dengan tipe data sesuai dengan jenis data yang akan ditampung.

\section{4) Tabel Pengaturan}

Tebel 2 Tabel Pengaturan

\begin{tabular}{c|l|c|c|l}
\hline No & \multicolumn{1}{c}{ Nama Field } & \multicolumn{1}{c}{$\begin{array}{l}\text { Tipe } \\
\text { Data }\end{array}$} & Lebar & Keterangan \\
\hline 1 & $\begin{array}{l}\text { id_pengatura } \\
\text { n }\end{array}$ & varchar & 5 & Id Pengaturan \\
\hline 2 & header & varchar & 30 & header \\
\hline 3 & Footer & varchar & 30 & footer \\
\hline 4 & $\begin{array}{l}\text { role_id_main } \\
\text { tance }\end{array}$ & Int & 11 & $\begin{array}{l}\text { Pengaturan } \\
\text { role }\end{array}$ \\
\hline 5 & Icon & varchar & 30 & ikon \\
\hline 6 & $\begin{array}{l}\text { email_error_- } \\
\text { acces }\end{array}$ & varchar & 100 & Emali error \\
\hline
\end{tabular}

Dari tabel 2 menampilkan tabel pengaturan, yang terdiri dari 6 field atau variabel dengan tipe data sesuai dengan jenis data yang akan ditampung.

5) Tabel Lokasi

Tabel 3 Tabel Lokasi

\begin{tabular}{|c|c|c|c|c|}
\hline No & Nama Field & $\begin{array}{l}\text { Tipe } \\
\text { Data } \\
\end{array}$ & Lebar & Keterangan \\
\hline 1 & id_lokasi & varchar & 11 & Id lokasi peta \\
\hline 2 & nama_lokasi & varchar & 35 & $\begin{array}{l}\text { nama lokasi } \\
\text { peta }\end{array}$ \\
\hline 3 & koord_x & float & & $\begin{array}{l}\text { Koordinat } \\
\text { longitude (data } \\
\text { spasial) }\end{array}$ \\
\hline 4 & koord_y & float & & $\begin{array}{l}\text { Koordinat } \\
\text { latitude (data } \\
\text { spasial) }\end{array}$ \\
\hline 5 & Foto & varchar & 60 & Foto Lokasi \\
\hline
\end{tabular}

Dari tabel 3 menampilkan tabel pengaturan, yang terdiri dari 5 field atau variabel dengan tipe data sesuai dengan jenis data yang akan ditampung. 
6) Tabel Kelurahan

Tabel 4 Tabel Kelurahan

\begin{tabular}{c|l|c|c|l}
\hline \multicolumn{2}{c}{ No } & \multicolumn{2}{c}{ Nama Field } & \multicolumn{2}{c}{$\begin{array}{c}\text { Tipe } \\
\text { Data }\end{array}$} & Lebar & $\begin{array}{l}\text { Keterang } \\
\text { an }\end{array}$ \\
\hline 1 & kode_Kelurahan & varchar & 10 & $\begin{array}{l}\text { Kode } \\
\text { Kelurahan }\end{array}$ \\
\hline 2 & nama_Kelurahan & varchar & 25 & $\begin{array}{l}\text { Nama } \\
\text { Kelurahan }\end{array}$ \\
\hline 3 & alamat_Kelurahan & char & & $\begin{array}{l}\text { Alamat } \\
\text { Kelurahan }\end{array}$ \\
\hline 4 & id_lokasi & varchar & 11 & $\begin{array}{l}\text { Id lokasi } \\
\text { peta }\end{array}$ \\
\hline 5 & koord_x & float & & $\begin{array}{l}\text { Koordinat } \\
\text { longitude } \\
\text { (data } \\
\text { spasial) }\end{array}$ \\
\hline 6 & koord_y & float & & $\begin{array}{l}\text { Koordinat } \\
\text { latitude } \\
\text { (data } \\
\text { spasial) }\end{array}$ \\
\hline 7 & Foto & varchar & 60 & $\begin{array}{l}\text { Foto } \\
\text { Lokasi }\end{array}$ \\
\hline
\end{tabular}

Tabel 4 menampilkan tabel kelurahan, yang terdiri dari 7 field atau variabel dengan tipe data sesuai dengan jenis data yang akan ditampung, field id_lokasi, koord_x, field koord_y dan foto lokasi adalah field atau variabel yang akan menyimpan data spasial.

7) Tabel Penduduk

Tabel 5 Tabel Penduduk

\begin{tabular}{|c|c|c|c|c|}
\hline No & Nama Field & $\begin{array}{l}\text { Tipe } \\
\text { Data }\end{array}$ & Lebar & $\begin{array}{c}\text { Keterang } \\
\text { an }\end{array}$ \\
\hline 1 & NIK & varchar & 16 & $\begin{array}{l}\text { Nomor } \\
\text { Induk } \\
\text { Penduduk }\end{array}$ \\
\hline 2 & P_Nama & varchar & 30 & $\begin{array}{l}\text { Nama } \\
\text { Penduduk }\end{array}$ \\
\hline 3 & P_Jenkel & varchar & 9 & $\begin{array}{l}\text { Jenis } \\
\text { Kelamin } \\
\text { Penduduk }\end{array}$ \\
\hline 4 & P_Tempat & varchar & 30 & $\begin{array}{l}\text { Tempat } \\
\text { Tgl Lahir }\end{array}$ \\
\hline 5 & P-Tanggal & Date & & $\begin{array}{l}\text { Tanggal } \\
\text { Lahir } \\
\end{array}$ \\
\hline 6 & P_Agama & varchar & 15 & $\begin{array}{l}\text { Agama } \\
\text { Penduduk }\end{array}$ \\
\hline 7 & $\underset{\mathrm{n}}{\mathrm{P} \_ \text {Pendidika }}$ & varchar & 25 & $\begin{array}{l}\text { Pendidika } \\
\mathrm{n} \\
\text { Terakhir }\end{array}$ \\
\hline 8 & P_SNikah & varchar & 15 & $\begin{array}{l}\text { Status } \\
\text { Pernikaha } \\
\mathrm{n}\end{array}$ \\
\hline 9 & $\begin{array}{c}\text { P_Pekerjaaa } \\
n\end{array}$ & varchar & 25 & Pekerjaan \\
\hline
\end{tabular}

\begin{tabular}{c|c|c|c|l}
\hline 10 & P_Goldarah & varchar & 2 & $\begin{array}{l}\text { Golongan } \\
\text { Darah }\end{array}$ \\
\hline 11 & P_Alamat & Char & & $\begin{array}{l}\text { Alamat } \\
\text { Penduduk }\end{array}$ \\
\hline 12 & $\begin{array}{c}\text { Kode_Keca } \\
\text { matan }\end{array}$ & varchar & 10 & $\begin{array}{l}\text { Kode } \\
\text { Keluraha } \\
\text { n }\end{array}$ \\
\hline 13 & $\begin{array}{c}\text { nama_Kelur } \\
\text { ahan }\end{array}$ & varchar & 25 & $\begin{array}{l}\text { Nama } \\
\text { Keluraha } \\
\text { n }\end{array}$ \\
\hline 14 & $\begin{array}{c}\text { kode_Keca } \\
\text { matan }\end{array}$ & varchar & 10 & $\begin{array}{l}\text { Kode } \\
\text { Kelurahan }\end{array}$ \\
\hline 15 & $\begin{array}{c}\text { nama_Keca } \\
\text { matan }\end{array}$ & varchar & 25 & $\begin{array}{l}\text { Nama } \\
\text { Kecamata } \\
\text { nam }\end{array}$ \\
\hline 17 & $\begin{array}{c}\text { kd_lokasi } \\
\text { koord_x }\end{array}$ & varchar & 11 & $\begin{array}{l}\text { Id lokasi } \\
\text { peta }\end{array}$ \\
\hline 19 & Foto & varchar & 60 & $\begin{array}{l}\text { Koordinat } \\
\text { longitude } \\
\text { (data } \\
\text { spasial) }\end{array}$ \\
\hline 18 & koord_y & float & $\begin{array}{l}\text { Koordinat } \\
\text { latitude } \\
\text { (data } \\
\text { spasial) }\end{array}$ \\
\hline
\end{tabular}

Tabel 5 menampilkan tabel penduduk, yang terdiri dari 19 field atau variabel dengan tipe data sesuai dengan jenis data yang akan ditampung, field id_lokasi, koord_x, field koord_y dan foto lokasi adalah field atau variabel yang akan menyimpan data spasial.

\subsection{Pembahasan}

1) Tampilan (interface) Menu Utama

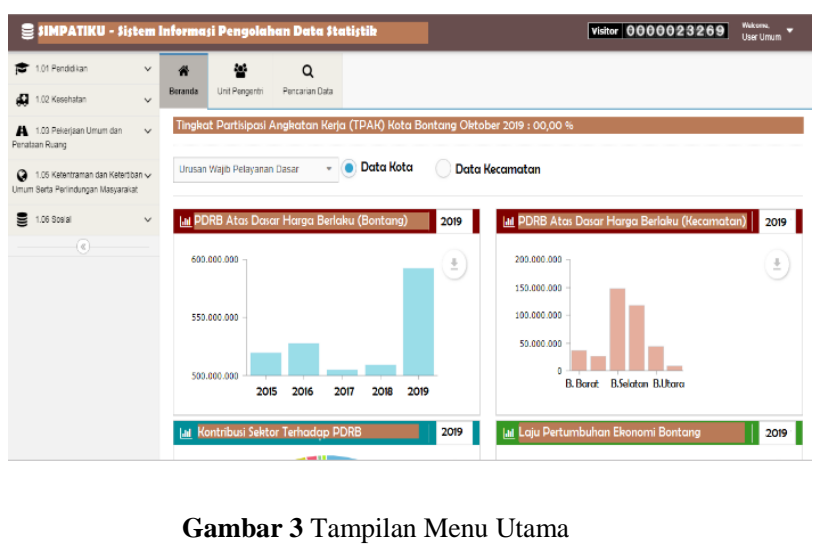

Gambar 3 menampilkan tampilan menu utama atau beranda sistem, yang memuat menu pendidikan, kesehatan, pekerjaan umum dan penataan ruang, 
JUST TI: (Jurnal Sains Terapan Teknologi Informasi) 12, 2 (Juli, 2020): 59-65

ISSN: 2579-4510(online) ISSN: 2085-6458(print)

ketentraman dan ketertiban umum serta perlindungan masyarakat, dan sosial. Pada tampilan ini juga terdapat ikon unit pengentri dan pencarian data serta grafik persentase data statistik.

\section{2) Tampilan Data Statistik Sektor Pendidikan}

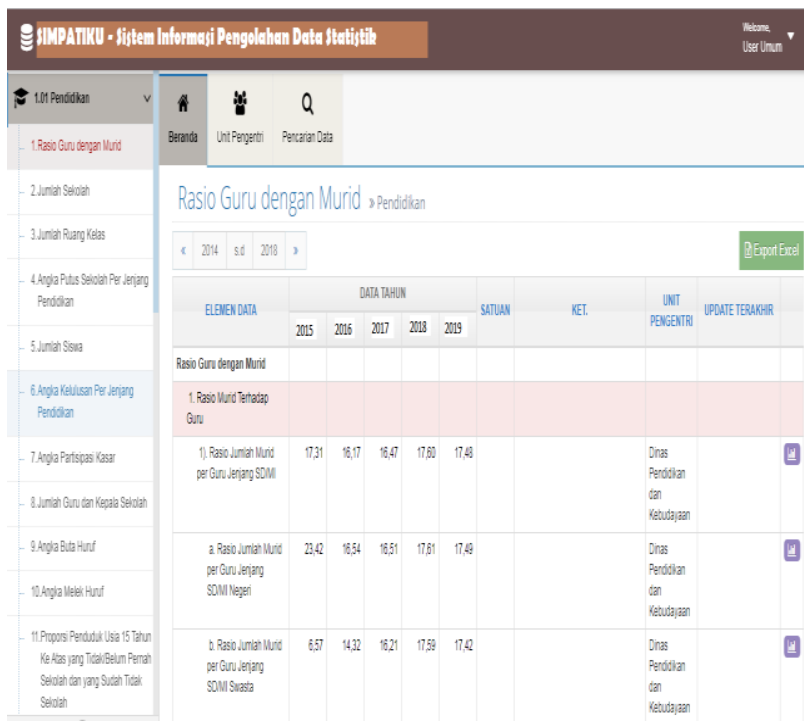

Gambar 4 Tampilan Data Statistik Sektor Pendidikan

Gambar 4 menampilkan data statistik pada sektor pendidikan, yang terdiri dari 27 item, yaitu rasio guru dengan murid, jumlah sekolah, jumlah ruang kelas, angka putus sekolah perjenjang Pendidikan, jumlah siswa, angka kelulusan per jenjang Pendidikan, angka partisipasi kasar, jumlah guru dan kepala sekolah, angka buta huruf, angka melek huruf, proporsi penduduk usia 15 tahun ke atas yang tidak/belum pernah sekolah dan yang sudah tidak sekolah. angka melanjutkan, jumlah siswa miskin, kualifikasi guru, kesetaraan SD, kesetaraan SMP, kesetaraan SMA, Pendidikan Taman KanakKanak, Pendidikan di tempat penitipan anak dan kelompok bermain atau yang sederajat, angka kelulusan, angka Pendidikan yang ditamatkan, rasio murid terhadap sekolah, beasiswa, indicator RPJMD dan indicator SDGS.

\section{3) Tampilan Data Statistik Jumlah Sekolah}

Pada tampilan ini menampilkan jumlah sekolah yang ada pada Dinas Pendidikan mulai tahun 2015 sampai dengan tahun 2019, dari tingkat
Pendidikan Anak Usia Dini (PAUD), tingkat Sekolah Dasar (SD), tingkat Sekolah Menengah Pertama (SMP), dan tingkat Sekolah Menengah Atas (SMA) dan Sekolah Menengah Kejuruan (SMK).

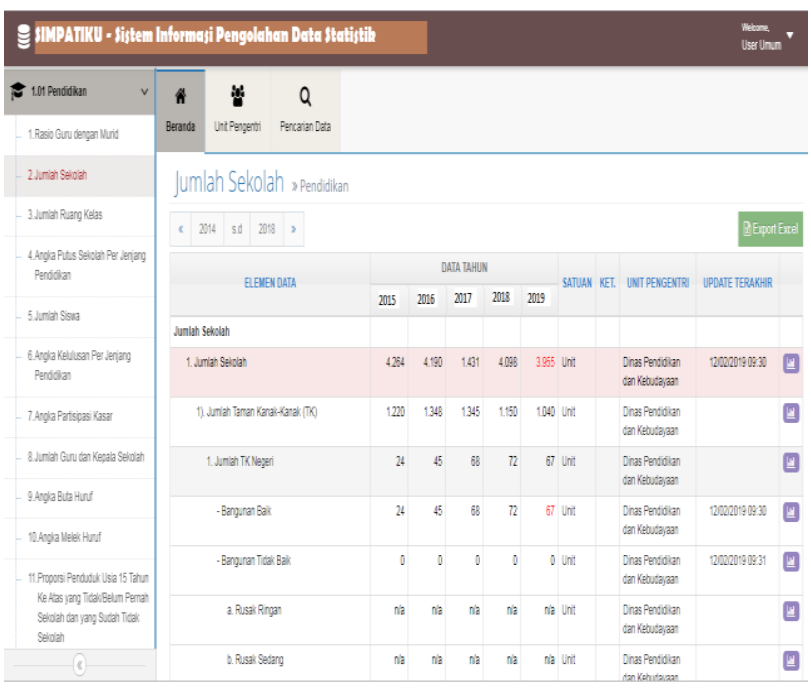

Gambar 5 Tampilan Data Statistik Jumlah Sekolah

Gambar 5 menggambarkan keadaan sekolah yang ada dalam lingkup dinas pendidikan Kota Bontang, baik sekolah negeri maupun sekolah swasta. Data statistik ini memuat jumlah sekolah dan kondisi masing-masing sekolah berdasarkan jenjang pendidikan.

\section{4) Tampilan Data Statistik Sektor Kesehatan}

Tampilan pada gambar berikut menampilkan data statistik pada sektor kesehatan kota Bontang.

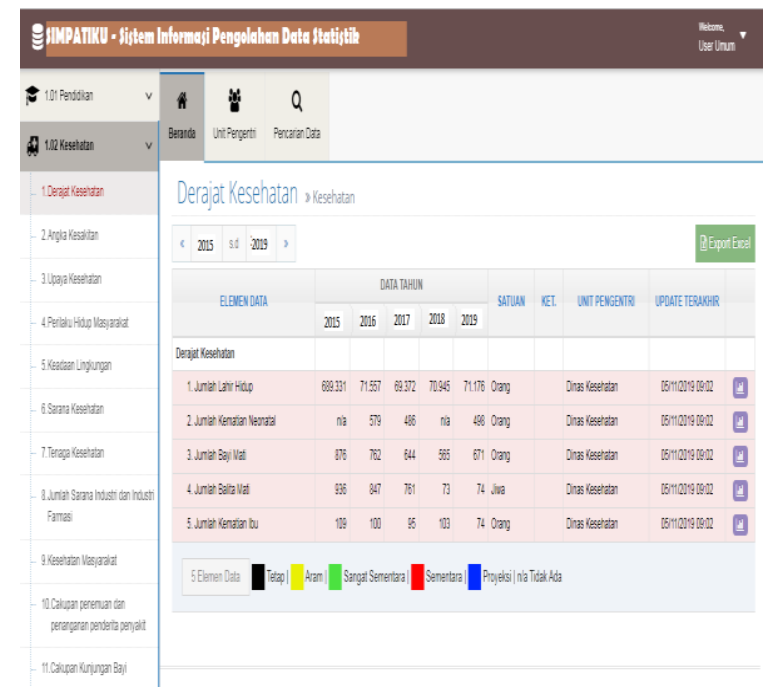


Gambar 6 Tampilan Data Statistik Sektor Kesehatan

Pada gambar 6 menampilkan data statistik pada sektor kesehatan yang terdiri dari 22 indikator yaitu derajat kesehatan, angka kesakitan, upaya kesehatan, perilaku kehidupan masyarakat, perilaku hidup masyarakat, keadaan lingkungan, sarana lingkungan, tenaga kesehatan, jumlah sarana industri dan industri farmasi, kesehatan masyarakat, cakupan penemuan dan penanganan penderita penyakit, cakupan kunjungan bayi, jumlah kasus kejadian luar biasa (KLB) / endemi pada manusia, jaminan kesehatan, rasio, penyakit tidak menular/degeneratif, rumah tangga yang mendapat layanan air bersih, cakupan pelayanan kesehatan rujukan pasien masyarakat miskin, cakupan kompilasi kebidanan, dan indikator RPJMD.

\section{5) Tampilan Data Statistik Sektor Sosial}

Gambar berikut menampilkan data statistik pada sektor social, yang terdiri dari 5 (lima) indicator yaitu penyandang masalah kesejahteraan social dan sarana kesejahteraan social, potensi dan sumber kesejahteraan social (PSKS), jumlah PMKS, jumlah kegiatan pembinaan terhadap LSM, yayasan dan oraganisasi sosial.

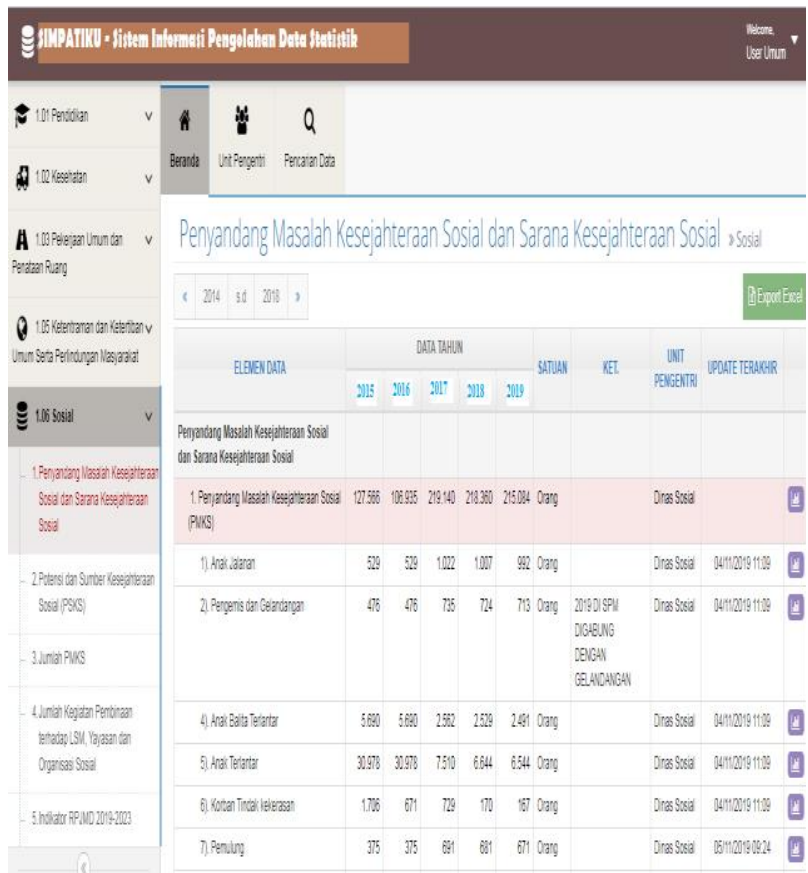

Gambar 7 Tampilan Data Statistik Sektor Sosial

\section{KESIMPULAN}

Penelitian telah menghasilkan prototye sistem informasi yang dapat dijadikan acuan untuk membangun sistem informasi pengolahan data statistik (SIMPATIKU) Kota Bontang, yang dapat mengolah data statitistik sektoral secara terpadu dan terintegrasi dengan sistem pengolahan data statistik pada organisasi perangkat daerah yang ada di pemerintah Kota Bontang.

\section{REFERENSI}

[1] Pressman. R,. "Rekayasa Perangkat Lunak: Pendekatan Praktisi ." Yogyakarta, Andi. 2015

[2] Pratama, Eka Agus,. "Sistem Informasi dan Implementasinya." Bandung: Informatika Bandung. 2014

[3] Nugroho A.. Perancangan dan Impementasi Sistem Basis Data. Yogyakarta: Andi Offset. 2011

[4] A. S., Rosa dan Shalahuddin, M.. Rekayasa Perangkat Lunak Terstruktur Dan Berorientasi Objek. Informatika. Bandung. 2013

[5] Siti, H., Irfan, D., \& Ridha H. Enterprise Architecture Fungsi Pengelolaan Data Statistik Sektoral Menggunakan TOGAF ADM (Studi Kasus Diskominfo Jabar). e-Proceeding of Enginering, III(5), 7114. 2018.

[6] Maulana, H.,. Perencanaan Arsitektur Teknologi Informasi Studi Kasus: PT. Perusahaan Pelayaran Nusantara Panurjwan Sebagai Agen Mediterranean Shipping Company.VUniversitas Indonesia. Jurnal Teknik Informatika, 4 (1). 2015

[7] Suhendri, S.,. Perancangan Arsitektur Sistem Informasi Sekolah dengan The Open Group Architecture Framework (Togaf)(Studi Kasus: Pondok Pesantren Ar-Rahmat). Infotech Journal, 1 (2), 40-47. 2016.

[8] Fahrianto,Feri, Victor A, dan Aenun,. Perencanaan Infrastruktur Teknologi Informasi di Lembaga Penelitian (LEMLIT) UIN Syarif Hidayatullah Jakarta Menggunakan TOGAF Architecture Development Method (ADM), Jurnal Teknik Informatika, UIN Syarif Hidayatullah, Jakarta, Vol.8, No.2. 2015.

[9] Wiyana W, dan Wing.W,. Sistem Panjaminan Mutu Pendidikan Dengan TOGAF ADM Untuk Sekolah Menengah Kejuruan, Jurnal Ilmiah Teknlogi Sistem Informasi, Yogyakarta, Vol.1, No.1. 2015.

[10] Raimond, L.W.,. Perencanaan Strategis Sistem Informasi/Teknologi Informasi Menggunakan Kerangka The Open Group Architecture Framework (TOGAF) (Studi Kasus : PEMDA Kabupaten Sumba Barat), Jurnal Terapan Teknologi Informasi, Universitas Kristen SatyaWacana, Salatiga. 2012. 